\title{
The replacement of protein concentrates by synthetic lysine in the diet of growing pigs*
}

\author{
By R. BRAUDE, K. G. MITCHELL, A. W. MYRES \\ AND M. J. NEWPORT \\ National Institute for Research in Dairying, Shinfield, Reading \\ AND A. CUTHBERTSON \\ Meat and Livestock Commission, Bletchley $R G 2,9 T$ \\ (Received 26 April г971 - Accepted I9 fuly 1971)
}

\begin{abstract}
I. Pigs from 20 to $60 \mathrm{~kg}$ live weight were fed on cereal diets, supplemented only with vitamins and minerals, with and without supplementary lysine.

2. Growth rate, feed:gain ratio and carcass quality of pigs given a high-barley diet ( $75 \%$ barley meal, $23 \%$ wheat offal) were inferior to those of pigs given a high-wheat offal diet (75\% wheat offal, $23 \%$ barley meal).

3. On both diets, but particularly on the high-barley diet, performance was improved by the addition of L-lysine (to give a total lysine content of $5.2 \mathrm{~g} / \mathrm{I} 6 \mathrm{~g}$ nitrogen, approximating to that present in a standard barley meal-wheat offal diet supplemented with $7 \%$ white fish meal).

4. Percentage $\mathrm{N}$ retention was improved on both diets by supplementation with lysine.

5. Results for carcass composition showed that the carcasses of pigs fed on the unsupplemented high-wheat offal diet contained more lean tissue than those of pigs given the unsupplemented high-barley diet. Lysine supplementation resulted in an increased content of lean tissue on both diets, the percentage increase due to lysine being greater (but not significantly so) on the high-barley diet. The increased lean content was reflected in the carcass measurements but not in the total $\mathrm{N}$ retention values, which did not differ significantly between treatments.

6. The results are discussed in relation to the shortage and high cost of animal protein concentrates and the possible replacement of these concentrates with synthetic amino acids.
\end{abstract}

Pig diets are normally based on cereals; protein concentrates are added to increase the total protein content and to counteract any essential amino acid deficiencies in the basal diet.

The importance of the lysine content of the diet is well established and there are many examples in the literature of the improvement in performance that can be brought about by lysine supplementation of diets containing poor-quality proteins (Evans, I960; Jones, Hepburn, Cadenhead \& Boyne, I962; Rerat \& Lougnon, I965; Ostrowski, I969). It has also been reported that small improvements in performance can be obtained when lysine is added to diets containing white fish meal, the protein concentrate most commonly used in this country, but economic appraisal of the results showed that this was not a viable proposition at present prices (Braude $\&$ Lerman, 1970). However, the greatest value of lysine supplementation may lie in the possible replacement of protein concentrates, since the latter are by far the most expensive dietary components. It has been reported that feeding with cereal mixtures supplemented with lysine, threonine, tryptophan, methionine, and in some experiments

* A preliminary account of this work has been presented (R. Braude, K. G. Mitchell, M. J. Newport \& A. Cuthbertson (1968), Proc, and Wld Conf. Anim. Prod., Maryland p. 350). 
also isoleucine, results in performance equal to that obtained with diets containing protein concentrates (Robinson \& Lewis, 1963; Müller, Palkoska, Dřevjaný \& Moravec, 1967 ). Later work showed that 'monodiets', i.e. single cereal diets with added amino acids, could be used successfully to rear pigs from weaning (Müller \& Málek, 1967 ). The present experiment was designed to test whether the supplementation of a cereal diet with lysine alone (to give a dietary lysine content/unit of protein approximating to that contained in a barley-wheat offal diet supplemented with $7 \%$ white fish meal) would significantly improve the performance of the pigs.

\section{EXPERIMENTAL}

Pigs of the Large White breed from the Shinfield enzootic pneumonia-free herd were used. Four castrated male litter-mates were allocated at random to the four dietary treatments shown in Table $\mathrm{r}$. There were six replicates of each treatment. The pigs started on their treatments at about 9 weeks of age when they weighed about $20 \mathrm{~kg}$.

\section{Table I. Percentage composition of the experimental diets in treatments $A-D$}

\begin{tabular}{|c|c|c|c|c|}
\hline Ingredient & A & $\mathrm{B}$ & $\mathrm{C}$ & $\mathrm{D}$ \\
\hline Barley meal & $74 \cdot 50$ & $74 \div 75$ & $22 \cdot 80$ & $22 \cdot 80$ \\
\hline Fine wheat offal & $22 \cdot 80$ & 22.80 & $74 \cdot 52$ & $74 \cdot 75$ \\
\hline L-Lysine hydrochloride & 0.25 & 一 & 0.23 & - \\
\hline Vitamin mixture* & 0.20 & 0.20 & 0.20 & \\
\hline Limestone flour $\left(\mathrm{CaCO}_{3}\right)$ & I.75 & I $\cdot 75$ & I'75 & $I \cdot 75$ \\
\hline Common salt $(\mathrm{NaCl})$ & 0.50 & 0.50 & 0.50 & 0.50 \\
\hline
\end{tabular}

* Based upon Agricultural Research Council ( 1967 ) estimates of nutrient requirements; $2 \mathrm{~kg}$ of mixture contained the following amounts of vitamins: riboflavin $3.25 \mathrm{~g}$, nicotinamide $15^{\prime} 75 \mathrm{~g}$, pantothenic acid $13.00 \mathrm{~g}$, pyridoxine $3.25 \mathrm{~g}$, vitamin $\mathrm{B}_{12} 13 \mathrm{mg}$, choline $200 \mathrm{~g}$, vitamin A $2.5 \times 10^{6}$ i.u., vitamin D $3 \cdot 0 \times 10^{5}$ i.u., vitamin E $2 \cdot 0 \mathrm{~g}$.

Two types of cereal diet were used, one consisting of about three parts barley meal and one part fine wheat offal, the other of three parts fine wheat offal and one part barley meal. The former diet was substantially lower in crude protein, and somewhat higher in its calculated energy content.

The percentage composition of the diets is given in Table I. L-Lysine hydrochloride was added to the diet in treatments $A$ and $C$ to give a total lysine content of $5.2 \mathrm{~g} /$ I6 $\mathrm{g}$ nitrogen. Approximately this amount of lysine would be supplied by the standard control diet used at Shinfield, containing barley, wheat offal and white fish meal $(7 \%)$. The amino acid composition of the complete diets is given in Table 2 together with the calculated digestible energy and crude protein contents. The procedure for amino acid analysis has been described by Barber, Braude, Mitchell $\&$ Myres (1971).

The pigs were fed twice daily to a scale based on live weight (Braude \& Mitchell, 195I). Water was added to the feed in the ratio of 2.51 water $/ \mathrm{kg}$ feed immediately before feeding. At intervals of approximately 3 weeks the pigs were placed in metabolism crates for $\mathrm{N}$ balance studies. The collection of excreta and analytical methods have been described in an earlier publication (Barber et al. 1971). 
When the pigs reached $60 \mathrm{~kg}$ live weight they were sent to slaughter. Carcass measurements were taken according to the procedure of Buck, Harrington \& Johnson (1962). One side of each carcass was dissected into lean, fat, bone and remainder, following a procedure similar to that described by Cuthbertson \& Pomeroy (I962) except that the separation of the tissues was carried out carefully with a butcher's knife rather than with scalpels and scissors.

Table 2. Crude protein and lysine contents, amino acid composition and calculated digestible energy and crude fibre contents of the experimental diets in treatments $A-D$

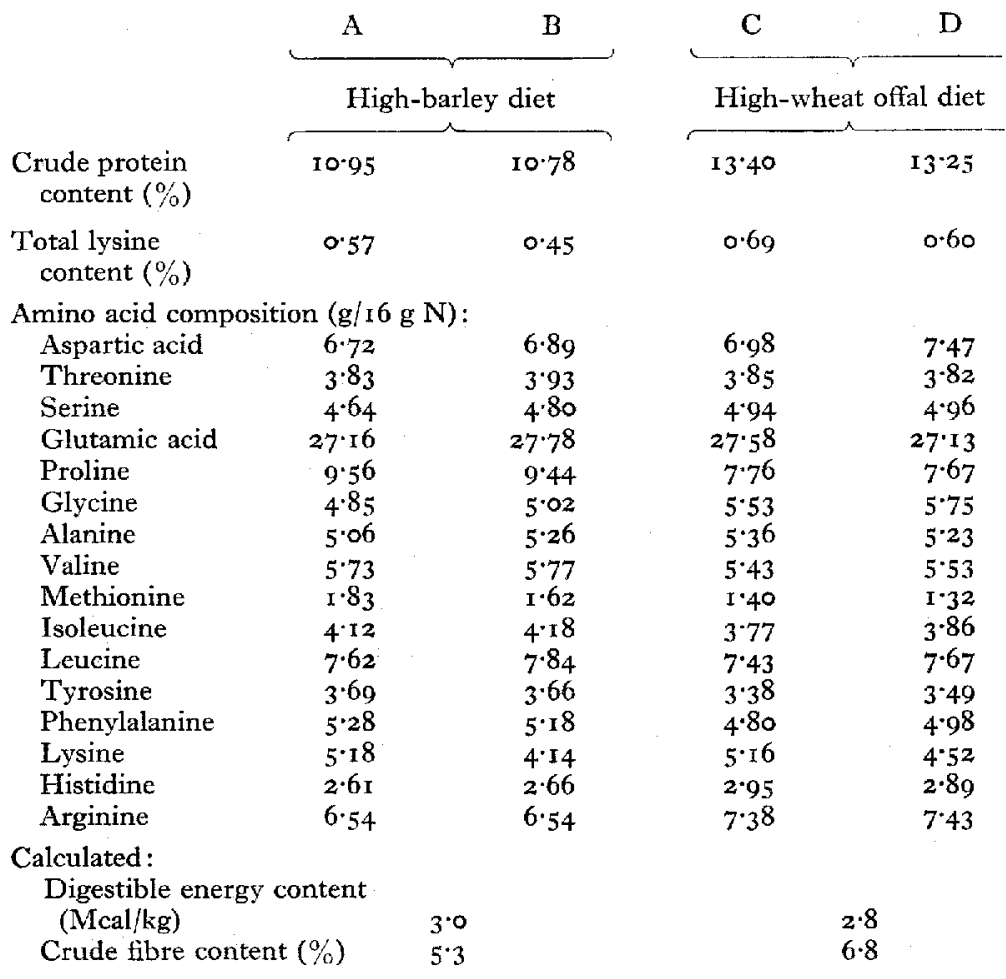

\section{RESULTS}

The results given in Table 3 show that lysine supplementation of each of the two basal diets resulted in significant improvements in growth rate and feed:gain ratio; the two lysine-supplemented diets gave results that were not significantly different from one another. There were no major differences in the total amount of $\mathrm{N}$ retained although $\mathrm{N}$ retention as a percentage of intake tended to be higher on both of the lysine-supplemented diets than on the other two diets.

The results for body composition, summarized in Table 4, show that there were significant differences in the amounts of lean and fat in the carcasses; the unsupplemented high-barley diet produced carcasses with the lowest lean and highest fat content while the lysine-supplemented high-wheat offal diet produced carcasses with the greatest lean and the lowest fat content. 
Table 3. Growth and nitrogen metabolism results for pigs in treatments $A-D$ given a highbarley or a high-wheat offal diet with and without supplementary lysine (six pigs per treatment)

\begin{tabular}{|c|c|c|c|c|c|c|}
\hline & $\mathbf{A}$ & $\mathbf{B}$ & $\mathrm{C}$ & $\mathrm{D}$ & \multirow{3}{*}{$\begin{array}{c}\text { Standard } \\
\text { error of } \\
\text { a mean } \\
\text { (15 df) }\end{array}$} & \multirow{3}{*}{$\begin{array}{l}\text { Results of } \\
\text { significance } \\
\text { tests* }\end{array}$} \\
\hline & \multicolumn{2}{|c|}{ High-barley diet } & \multicolumn{2}{|c|}{ High-wheat offal diet } & & \\
\hline & +lysine & -lysine & +lysine & - Iysine & & \\
\hline Daily gain $(\mathrm{kg} / \mathrm{d})$ & 0.53 & 0.39 & 0.55 & 0.48 & 0.012 & B D A C \\
\hline Feed:gain ratio $(\mathrm{kg} / \mathrm{kg})$ & 3.01 & 4.09 & 3.08 & $3 \cdot 36$ & 0.064 & $\underline{\mathrm{AC}} \overline{\mathrm{DB}}$ \\
\hline Total $\mathrm{N}$ retention $\dagger(\mathrm{g})$ & 996 & 992 & r 120 & 1026 & $46 \cdot 0$ & $\overline{\mathrm{BA}} \mathrm{DC}$ \\
\hline $\mathrm{N}$ retained as percentage & 45 & 36 & $4 I$ & 35 & $\mathrm{I} \cdot 8$ & $\overline{\mathrm{DBCA}}$ \\
\hline
\end{tabular}

* Treatment means not underscored by the same line are significantly different at the $5 \%$ level of probability (Duncan, 1955).

+ Over the whole experimental period, extrapolated from four balance periods for each pig.

\section{Table 4. Carcass characteristics of pigs in treatments A-D given a high-barley} or a high-wheat offal diet with and without supplementary lysine

\begin{tabular}{|c|c|c|c|c|c|c|}
\hline & A & $\mathbf{B}$ & C & $\mathrm{D}$ & \multirow{3}{*}{$\begin{array}{l}\text { Standard } \\
\text { error of } \\
\text { a mean* }\end{array}$} & \multirow{3}{*}{$\begin{array}{l}\text { Results of } \\
\text { significance } \\
\text { tests } \uparrow\end{array}$} \\
\hline & \multicolumn{2}{|c|}{ High-barley diet } & \multicolumn{2}{|c|}{ High-wheat offal diet } & & \\
\hline & + lysine & -lysine & + lysine & -lysine & & \\
\hline Lean $(\%$ of side $)$ & $48 \cdot 3$ & $42 \cdot 5$ & $56 * 7$ & $52 \cdot 8$ & 0.89 & B A D C \\
\hline Fat $(\%$ of side) & $33 \cdot 7$ & $40 \cdot 1$ & $24 \cdot 1$ & $27 \cdot 9$ & 0.87 & C D A B \\
\hline Bone ( $\%$ of side) & $12 \cdot 2$ & $12 \cdot 7$ & $13 \cdot 6$ & $13 \cdot 3$ & 0.21 & $\triangle \mathrm{BDC}$ \\
\hline Remainder ( $\%$ of side) & $5 \cdot 8$ & $4 \cdot 7$ & $5 \cdot 6$ & $6 \cdot 0$ & 0.18 & $\mathrm{BC} \overline{\mathrm{AD}}$ \\
\hline Length (mm) & 715 & 714 & 712 & 726 & $3 \cdot 8$ & $\mathrm{CBAD}$ \\
\hline Depth (mm) & 274 & $28 r$ & 273 & 267 & 3.5 & $\mathrm{DCA} B$ \\
\hline Shoulder fat (mm) & $33 \cdot 0$ & $36 \cdot 3$ & $25 \cdot 5$ & $27 \cdot 8$ & 0.94 & $\mathrm{CDAB}$ \\
\hline Mid-back fat (mm) & $14 * 4$ & $16 \cdot 5$ & II $\cdot 5$ & I $3 \cdot 2$ & 0.89 & CDAB \\
\hline Minimum loin fat (mm) & I 5.4 & $20 \cdot 0$ & IO.5 & $12 \cdot 4$ & 0.82 & $\mathrm{CDAB}$ \\
\hline \multicolumn{7}{|c|}{ Eye muscle (longissimus dorsi) } \\
\hline Width (mm) & $71 \cdot 4$ & $65 \cdot 7$ & $74 \cdot 7$ & $70 \cdot 0$ & $r \cdot 69$ & $\mathrm{BDAC}$ \\
\hline Depth (mm) & $4 I \cdot 8$ & $33: 3$ & 40.5 & $40 \cdot 8$ & $\Sigma \cdot 33$ & $\mathrm{BCDA}$ \\
\hline Area $\left(\mathrm{cm}^{2}\right)$ & $2 I \cdot 5$ & $14 \cdot 9$ & 23.0 & $20 \cdot 6$ & 0.89 & $\mathrm{~B} \overline{\mathrm{DAC}}$ \\
\hline Fat ' $\mathrm{C}$ ' $(\mathrm{mm}) \ddagger$ & $16 \cdot 4$ & $I 8 \cdot 8$ & 10.3 & $12 \cdot 0$ & 0.80 & $\mathrm{CDAB}$ \\
\hline Fat ' $K$ ' $(\mathrm{mm})\rfloor$ & $20 \cdot 0$ & $25^{\circ} 0$ & $13 \cdot 8$ & $15 \cdot 8$ & $I \cdot 44$ & $\overline{\mathrm{CD}} \overline{\mathrm{AB}}$ \\
\hline Streak thickness (mm) & $29 \cdot 0$ & $26 \cdot 5$ & $21 \cdot 3$ & $20 \cdot 2$ & $1 \cdot 75$ & $\mathrm{DCBA}$ \\
\hline
\end{tabular}

* Standard error of a mean of six observations with $\mathrm{I}_{3} \mathrm{df}$ applies strictly only to B and C (A and D are the means of five observations).

$\dagger$ Treatment means not underscored by the same line are significantly different at the $5 \%$ level of probability (Duncan, 1955).

$\mp$ 'Thickness of back fat surrounding the eye muscle measured approximately $5.5 \mathrm{~cm}$ (fat ' $\mathrm{C}$ ') and I I $\mathrm{cm}$ (fat ' $\mathrm{K}$ ') from the mid-line of the back. 
The linear back fat measurements shown in Table 4 confirmed the higher fat content of the pigs given the unsupplemented high-barley diet, and most of these measurements were significantly reduced by lysine supplementation of the barley diet. The lysine also appeared to have the effect of increasing the eye muscle (longissimus dorsi) area. The linear fat measurements for pigs given the high-wheat offal diet supplemented with lysine gave the lowest fat values, which agreed with the carcass dissection results, but these values were not significantly different from those for pigs fed on the unsupplemented high-wheat offal diet.

The percentage improvement due to lysine supplementation was greater on the high-barley diet than on the high-wheat offal diet (although the differences were not statistically significant) for growth rate and feed:gain ratio, although the results for $\mathrm{N}$ retention did not follow this pattern. The effect of lysine in increasing carcass lean and decreasing carcass fat was also more marked with the high-barley diet, but in most instances the differences in response on the two diets were small and not significant.

\section{DISCUSSION}

From the results obtained in this experiment it may be concluded that growing pigs can perform reasonably well on cereal diets supplemented only with vitamins and minerals provided additional lysine is given. Whether the growth rates and feed:gain ratios obtained in the present study would have been further improved by the addition of a protein concentrate, such as white fish meal, is not known. However, in a subsequent experiment in which a similar lysine-supplemented high-wheat offal diet was directly compared with a more conventional diet containing cereals plus $7 \%$ fish meal, a significantly better performance was obtained on the latter diet (Barber, Braude \& Mitchell, I969).

The effect of dietary treatment on tissue protein synthesis, as shown by the lean content of the carcass, was striking. In treatment $\mathrm{C}$ the diet contained the highest amount of lysine $(0.69 \%)$ and the carcasses of the pigs on this treatment contained the greatest amount of lean tissue. In treatment $B$ the diet contained the lowest amount of lysine $(0.45 \%)$ and the carcasses of the pigs on this treatment contained the smallest amount of lean tissue. This would seem reasonable if lysine was the factor limiting protein synthesis. However, the average lean content on treatment D (unsupplemented wheat offal) was 4.5 percentage units higher than on treatment A (lysine-supplemented barley) whereas there was only a relatively small difference in the lysine content of the two diets ( 0.60 and $0.57 \%$ respectively). It is possible that the response to addition of lysine to the high-barley diet was limited by either the level of total $\mathrm{N}$ in that diet, which was appreciably lower than in the wheat offal diet, or a lower biological availability of lysine or other essential amino acids. Preliminary attempts to improve the response to lysine by increasing total dietary $\mathrm{N}$ using diammonium phosphate have proved unsuccessful (Barber et al. 1969), so it seems likely that the response was limited not by a lack of non-essential amino acids but by a deficiency of one or more essential amino acids. Other work suggests that threonine is the second limiting amino acid for pigs, since supplements of lysine and threonine to a cereals diet produced 
performance equal to that of pigs fed on protein-supplemented control diets (Müller, Kozel, Hejzlar, Bauer \& Moravec, 1967). Our studies (unpublished) on blood plasma amino acids in pigs have given similar indications, since lysine supplementation resulted in a progressive decrease in plasma threonine concentration.

The results for total $\mathrm{N}$ retention are somewhat anomalous in that, whereas all the treatment means for lean content were significantly different from one another, there were no significant differences in the values for $\mathrm{N}$ retention. It seems logical to expect that the total amount of $\mathrm{N}$ retained by a growing animal would be reflected in the lean content of the carcass, and several workers have demonstrated such a relationship. However, in another study an increase in $\mathrm{N}$ retention was not reflected in any significant change in the lean content of the carcass (Braude, Mitchell, Myres \& Cuthbertson, 1969); in this experiment the protein intakes of the pigs were appreciably higher than normal and the lack of correspondence could possibly be explained by larger errors (which are cumulative and positive) in the measurement of $\mathrm{N}$ retention. It is apparent that there are many unsolved problems concerning the relation between $\mathrm{N}$ retention and carcass leanness in pigs, and hasty conclusions should be avoided.

The results of the present study show clearly that cereal diets can be improved by supplementation with lysine and they illustrate the importance of taking into account the lysine content of the cereal component of a diet. It has been shown that variation in the lysine content of barley can have considerable influence on the performance of pigs fed on diets supplemented with white fish meal (Jones, Cadenhead \& Livingstone, 1968 ). Since a high proportion of the total protein of a conventional diet is provided by the cereal component, it is unfortunate that methods for the determination of the available amino acid content of cereal proteins have not proved easy to develop. It is well known that one of the roles of protein concentrates is to counteract amino acid deficiencies (usually of lysine in pigs) in the cereal component of a diet, and this almost inevitably means adding an excess of other amino acids which are not needed for protein synthesis. In order to reduce this excess as much as possible, it is nccessary to have a thorough knowledge of dietary amino acid content and availability and of the amino acid requirements of the pig. The shortage and high cost of animal protein for use in feeding-stuffs is likely to increase, so that further studies on the problems of supplementation of cereal proteins with synthetic amino acids, provided they can be made available at a suitable price, are urgently required.

We thank Mr M. R. Jones for statistical analysis of the experimental results. One of us (A.W.M.) was in receipt of a postgraduate award from the Meat and Livestock Commission (formerly PIDA). We are grateful to A.E.C. - Société de Chimie Organique and Biologique of Paris and Commentry, France and Bourbon Products Ltd, London, for a gift of lysine. 


\section{REFERENCES}

Agricultural Research Council (1967). The Nutrient Requirements of Farm Livestock. No. 3. Pigs. London: H. M. Stationery Office.

Barber, R. S., Braude, R. \& Mitchell, K. G. (r969). Anim. Prod. r , 292.

Barber, R. S., Braude, R., Mitchell, K. G. \& Myres, A. W. (1971). Br. F. Nutr. 25, 285.

Braude, R. \& Lerman, P. (1970). F. agric. Sci., Camb. 74, 575.

Braude, R. \& Mitchell, K. G. (195 I). F. Minist. Agric. Fish. 57, 501.

Braude, R., Mitchell, K. G., Myres, A. W. \& Cuthbertson, A. (I969). Anim. Prod. rx, 292.

Buck, S. F., Harrington, G. \& Johnson, R. F. (1962). Anim. Prod. 4, 25.

Cuthbertson, A. \& Pomeroy, R. W. (1962). Y. agric. Sci., Camb. 59, 207.

Duncan, D. B. (1955). Biometrics II, $\mathrm{x}$.

Evans, R. E. (1960). F. agric. Sci., Camb. 54, 266.

Jones, A. S., Cadenhead, A. \& Livingstone, R. M. (1968). F. Sci. Fd Agric. r9, 446.

Jones, A. S., Hepburn, W. R., Cadenhead, A. \& Boyne, A. W. (1962). Anim. Prod. 4, I85.

Müller, Z., Kozel, V., Hejzlar, Z., Bauer, B. \& Moravec, J. (1967). Biologizace Chem. Vyz. Zvir. 3, 4 I I.

Müller, Z. \& Málek, I. (1967). Biologizace Chem. Vyz. Zvir. 3, 535.

Müller, Z., Palkoska, J., Dřevjaný, L. \& Moravec, J. (1967). Biologizace Chem. Vyz. Zvir. 3, 423.

Ostrowski, H. (1969). Anim. Prod. Ir, 521 .

Rerat, A. \& Lougnon, J. (1965). Annls Zootech. 14, 247.

Robinson, D. W. \& Lewis, D. (1963). F. Sci. Fd Agric. 14, 806. 